\title{
PERAN ORGANISASI KEMAHASISWAAN DALAM MENUMBUHKAN NILAI SOLIDARITAS SOSIAL ANTAR MAHASISWA DI LINGKUNGAN FAKULTAS HUKUM DAN ILMU SOSIAL, UNIVERSITAS PENDIDIKAN GANESHA
}

\author{
Zainullah, I Wayan Mudana, Tuty Maryati \\ Progam Studi Pendidikan Sosiologi \\ Jurusan Sejarah,Sosiologi,Dan Perpustakaan \\ Universitas Pendidikan Ganesha \\ Singaraja
}

Email :zainullah1718@gmail.com, mudanawayan60@gmail.com,Tuty.Maryati@undiksha.ac.id

\begin{abstract}
Abstrak
Penelitian ini bertujuan untuk mengetahui. (1). Progam kerja apakah yang ada di lembaga organisasi sosial di FHIS yang menumbuhkan nilai solidaritas (2). Apa sajakah hambatan bagi Himpunan Mahasiswa Jurusan dalam menumbuhkan sikap solidaritas antar mahasiswa. (3). Aspek-aspek apa sajakah dari organisasi sosial yang ada di lingkungan FHIS Undiksha yang memiliki potensi sebagai suplemen belajar di SMA. Penelitian ini merupakan penelitian kualitatif dengan analisis deskriptif. Metode analisis deskriptif dipilih dengan tujuan menggambarkan fenomena yang terjadi sesuai dengan fakta dan apa adanya. Metode pengumpulan data yang digunakan dalam penelitian ini adalah observasi, wawancara, dan dokumentasi. Adapun hasil dari penelitian ini adalah 1). Progam kerja yang dapat menumbuhkan nilai solidaritas di HMJ adalah: Clio fun day, bakti sosial, clio ajang sana, clio club, suka duka mahasiswa, mks (malam keakraban sejarah), pemeliharaan taman sejarah sedangkan untuk Perpustakaan meliputi, lomba mendongen, ulang tahun jurusan dan menggalang dana serta menyalurkan bantuan kemanusiaan.2). Hambatan bagi HMJ adalah masalah ekonomi, sumberdaya manusia, kurangnya partisipasi mahasiswa, egois, dan kurangnya rasa disiplin 3). Adapun potesinya yang dapat dijadikan suplemen pembelajaran yaitu nilai toleransi, nilai gotong royong dan rasa tanggung jawa
\end{abstract}

Kata kunci: Organisasi Kemahasiswaan, Solidaritas, Mahasiswa FHIS

\begin{abstract}
Abstrack
This study aims to determine. (1). What work programs exist in social organizations in FHIS that foster the value of solidarity (2). What are the obstacles for the Department of Student Association in fostering an attitude of solidarity between students. (3). What aspects of social organizations in the Undiksha FHIS environment have the potential to supplement learning in high school. This research is a qualitative research with descriptive analysis. Descriptive analysis method was chosen with the aim of describing phenomena that occur in accordance with facts and what they are. Data collection methods used in this study were observation, interviews, and documentation. The results of this study are 1). Work programs that can foster the value of solidarity at HMJ are: Clio fun day, social service, clio event there, clio club, ups and downs of students, mks (the night of historical intimacy), maintenance of historical parks while for the Library include, contest of contesting, birthday majors and raising funds and channeling humanitarian assistance.2). Barriers to HMJ are economic problems, human resources, lack of student participation, selfishness, and lack of discipline 3). The potentials that can be used as learning supplements are tolerance value, mutual cooperation value and a sense of responsibility
\end{abstract}

Keywords: Student Organizations, Solidarity, FHIS Students 


\section{Pendahuluan}

Organisasi merupakan sebuah wadah atau tempat berkumpulnya sekelompok orang utuk bekerja sama secara rasional dan sistematis, terkendali, dan terpimpin untuk mencapai sebuah tujuan tertentu dengan memanfaatkan sumber daya yang ada. Pada umumnya organisasi akan memanfaatkan berbagai sumber daya tertentu dalam rangka mencapai tujuan, seperti uang, metode/cara, lingkungan, sumber daya manusia dan sumber daya lainnya, yang dilakukan secara sistematis, rasional dan terkendali. Organisasi merupakan sebuah kerangka hubungan yang terstruktur yang didalamnya terdapat wewenang dan tanggung jawab serta pembagian kerja yang jelas untuk menjalankan sesuatu fungsi tertentu.

Mengacu pada makna dari
organisasi itu sendiri. Tujuan dari
organisasi tidak hanya fokus pada
tercapainya visi dan misi dari sebuah
perusahaan itu sendiri, namun juga
meningkatkan penghasilan yang melebihi
biaya produksi. Secara umum, organisasi
itu sendiri memiliki tujuan antara lain
sebagai berikut:

a. organisasi dapat dijadikan sebagai wadah untuk bersama sama mencapai sebuah tujuan yg direncanakan secara efektif

b. organisasi juga dapat meningkatkan kemampuan, kemandirian serta sumberdaya yang dimiliki

c. sebagai wadah bagi setiap individuindividu yang ingin memiliki jabatan, penghargaan, dan pembagian kerja.

Dalam sebuah organisasi tentu memiliki ciri-ciri yang dapat kita ketahui, salah satunya kita bisa lihat dari sisi keanggotaannya, sebuah organisasi biasanya memiliki sebuah anggota yang terdiri dari dua orang atau lebih, setiap anggota harus saling bekerja sama untuk mencapai sebuah tujuan, tanpa adanya kerja sama antar anggota organisasi maka tujuan tidak dapat tercapai secara efektif dan efisien.

Dari hal tersebut organisasi tidak lepas dari peraturan untuk menjaga kekompakan dan komitmen sesam anggota dari organisasi itu sendiri, dan setiap organisasi pasti memiliki peraturan namun organisasi satu berbeda peraturannya dengan organisasi yang lainnya. Peraturan ini dibuat untuk mengatur setiap anggota agar saling bersinergi dalam proses pencapaian tujuan dan menciptakan manajemen yang baik dalam organisasi. Untuk tercapainya sebuah tujuan dalam organisasi maka harus ada pembagian tugas dan tanggung jawab, tujuan dengan adanya peraturan tentu harus disertai dengan pembagian tugas dan tanggung jawab yang jelas pada setiap anggota organisasi. Pembagian tugas tersebut bisa dilakukan dewngan pembentukan beberapa divisi yang bertanggung jawab pada beberapa tugas dan tanggung jawab.

Organisasi tidak hanya terjadi di lingkungan masyarakat namun juga terjadi diberbagai pendidikan seperti formal, non formal dan informal. Bisa kita lihat dalam dunia pendidikan tidak bisa lepas dari organisasi itu sendiri seperti dalam pendidikan formal

Pendidikan formal seperti instusi sekolah dan perguruan tinggi. Disekolah organisasi sosial juga dapat kita temui seperti Osis, sedangkan di perguruan tinggi dapat kita jumpai seperi BEM dalam lingkup Universitas, SENAT terdapat dalam lingkup Fakultas dan HMJ dilingkup Jurusan

Dalam hal ini peneliti lebih fokus pada organisasi yang terdapat di Universitas terlebih khusus di lingkungan Fakultas dan Jurusan. Dengan alasan faktor solidaritas dalam kehidupan mahasiswa yang majemuk baik di lihat dari mata agama,suku, ras dan yang lainnya. Sehingga peneliti tertarik untuk melakukan penelitian kedalan organisasi mahasiswa tersebut karna di dalamnya 
terdapat kemajemukan dari setiap anggotanya.

Dalam lingkungan Universitas lebih khususnya dilingkungan Fakultas Hukum Dan IImu Sosial (FHIS) yang sumberdaya manusiannya (SDM) yaitu beragam dalam hal ini dikenal dengan istilah Multikulturalisme, baik dari hal budaya, adat, bahasa, etnis, ras, suku dan agama. Tentunya dari hal tersebut memiliki banyak macam bentuk interaksi, tak jauh beda dengan lembaga pendidikan lainnya, meskipun banyak perbedaan didalamnya. Sebagai pendukung sumber 'daya manusia dalam lingkungan kampus, interkasi merupakan penggerak dari jalannya sebuah organisasi.

Penelitian ini diharapkan dapat dijadikan sebagai suplemen pembelajaran dalam mata pelajaran sosiologi seperti materi: kelompok sosial, perbedaan, kesetaraan, harmoni sosial yang didalamnya terdapat materi solidaritas sosial. Lebih khususnya pada jenjang SMA kelas XI. Peneliti melihat ini bisa dijadikan suplemen pembelajaran karena sesuai dengan tuntutan kurikulum yang berlaku di sekolah itu sendiri baik dari hal silabus, sumber belajar maupun yang lainnya.

Berdasarkan uraian latar belakang
diatas, maka dapat dikemukakan beberapa permasalahan yang akan di kaji diantaranya:1. Progam kerja apakah yang ada di lembaga organisasi kemahasiswaan di FHIS yang menumbuhkan nilai solidaritas. 2. Apa sajakah hambatan bagi Himpunan Mahasiswa Jurusan dalam menumbuhkan sikap solidaritas sosial antar mahasiswa. 3.Aspek-aspek apa sajakah dari organisasi sosial yang ada di lingkungan FHIS Undiksha yang memiliki potensi sebagai suplemen belajar di SMA.Penelitianinimenarikuntuklebihdiketa huimakapenulismenggunakanjudul "Peran Organisasi Kemahasiswaan Dalam Menumbuhkan Nilai Solidaritas Sosial Antar Mahasiswa di Lingkungan Fakultas Hukum Dan IImu Sosial, Universitas Pendidikan Ganesha (Potensinya Sebagai Suplemen Belajar Sosiologi Di SMA)"

\section{METODE}

Langkah yang ditempuh oleh peneliti untuk mendapatkan jawaban atas persoalan yang timbul dari penelitian ini maka peneliti menggunakan metode sebagai berikut : 1) Rancangan penelitian, peneliti menggunakan pendekatan kualitatif yang menghasilkan data deskriptf berup aucapan, tulisan atau perilaku, 2) Lokasi penelitian ini dilakukan kampus universitas pendidikan ganesha lebih khusus kepada fakultas hukum dan ilmu sosial serta HMJ yang berada di bawah fakultas. 3)Penentuan informan menggunakan purposive sampling yaitu menentukan informan berdasarkan pertimbangan tertentu yakni orang yang dianggap mengetahui langsung tentang progam kerja yang dimiliki oleh HMJ, 4) Teknik pengumpulan data menggunakan observasi melalui pengamatan dan pencatatan, wawancara dengan melakukan Tanya jawab kepada para informan dan pihak-pihak yang berkaitan, dan studi dokumentas idengan mempelajari dokumen untuk mendapatkan data berupa data anggota mahasiswa yang masuk kedalam organisasi HMJ, serta dokumen-dokumen lain yang berkaitan dengan obyek yang diteliti, 5) Teknik penjaminan keabsahan data sebagai berikut;pertama, triangulasi metode yaitu mengecek keaslian data yang diperoleh dengan menggunakan teknik pengumpulan data observasi, wawancara, dand okumentasi, kedua, triangulasi sumber yaitu mengecek keabsahan data melalui sumber yang berbeda dan 6) Teknik pengolahan data untuk menyajikan informasi hasil dari penilitian ini yaitu menggunakan teknik analisis data yang meliputi;pertama, reduksi data yang merupakan kegiatan menyeleksi data dari hasil temuan observasi, wawancara, pencatatan untuk digolongkan supaya dapat disimpulkan, kedua, penyajian data dilakukan untuk menyajikan temuan yang diperoleh selama penelitian yang berupa tulisan derskriptif, table, matrik, grafik, dan bagan supaya mudah dimengerti dan ketiga, kesimpulan ini dilakukan sesudah terjadireduksi data dan penyajian data lalu 
kemudian disimpulkan atau diringkas hasil dari selama penelitian. Penulisan hasil penelitian dilakukan setelah semua data terkumpul kemudian peneliti menyajikan data hasil dari temuan secara deduktifinduktif yaitu menyajikan hal-hal yang umum terlebih dahulu kemudian kehal-hal yang lebih spesifik atau khusus.

\section{HASIL DAN PEMBAHASAN Sejarah Singkat Fakultas Hukum Dan IImu Sossial}

Fakultas Hukum dan IImu Sosial merupakan salah satu Fakultas yang berada di Undiksha. Undiksha sendiri merupakan Perguruan Tinggi Negeri (PTN) yang berada di Bali utara. Lebih tepatnya berada di daerah Singaraja. Berdirinya Fakultas Hukum dan IImu Sosial ini ditetapkan pada 1957. Eksistensi fakultas ini tidak dapat dilepaskan dari sejarah kebutuhan guru di indonesia. Diawali dengan berdirinya progam kursus pendidikan B-1Perniagaan pada tahun 1957, progam ini kemudian menjadi bagian dari FKIP Universitas Airlangga (Unair) pada januari 1962. Dengan adanya Universitas Udayana (Unud) di Bali. Status FKIP (Unair) kemudian diintregasikan kepada Unud di Bali dalam FKIP (Unud) pada bulan Agustus 1962. Tetapi, pada tahun 1963 sejalan dengan kebijakan pemerintah Indonesia melalui SK Presiden RI NO.1 Tahun 1963, status FKIP Unud kemudian diintegrasikan kepada IKIP Malang menjadi IKIP Malang Cabang Singaraja dengan rektor khusus. Pada saat inilah dibentuk jurusan IPS sebagai cikal bakal FIS dengan dua prodi yaitu pendidikan ekonomi/koperasi dan pendidikan Civic/Hukum.

Tidak berselang lama pada tahun 1968 IKIP Malang Cabang Singaraja diintegrasikan kembali kepada UNUD dan terbentuk dua fakultas, yaitu fakultas keguruan (FKG) dengan salah satunya pendidikan IPS dan fakultas ilmu pendidikan (FIP). Pada saat itu jurusan pendidikan IPS yang bernaung dibawah FKG telah memliki empat progam studi yaitu. Pendidikan Ekonomi, Pendidikan Civic/Hukum, Pendidikan Sejarah, Pendidikan Geografi. Pada tahun 1983.
Melalui kekuatan hukum Keppres RI NO.62 tahun 1982 tertanggal 18 Februari 1983, kedua fakultas tersebut dilebur lagi menjadi satu fakultas. Yaitu, FKIP UNUD Sigaraja yang salah satunya memiliki jurusan pendidikan IPS dengan empat progam studi tersebut mengalami sedikit perubahan yaitu PS Pendidikan. Ekonomi, PS PMP, PS Pendidikan. Sejarah, PS Pendidikan. Geografi

Dalam perkembangannya, berdasarkan SK Presiden NO.8 tahun 1993, status FKIP Singaraja menjadi sekolah tinggi pendidikan dan keguruan (STKIP) Negeri Singaraja dengan salah satunya memiliki jurusan pendidikan IPS dengan empat progam studi yaitu, Pendidikan Ekonomi, Pendidikan PPKN, Pendidikan Sejarah, Pendidikan Geografi. Delapan tahun kemudian, dengan perjuangan untuk meningkatkan status, melalui SK Presiden NO.19 Tahun 2001 Tertanggal 5 Februari 2001 STKIP Singaraja kembali mengalami peningkatan status menjadi IKIP Negeri Singaraja dengan salah satunya memiliki fakultas IPS dengan empat jurusan Pendidikan. Ekonomi, Pendidikan Ppkn, Pendidikan Sejarah, Pendidikan Geografi

Dalam perjalanan sejarahnya, IKIP Negeri Singaraja kemudian memperoleh progam pengembangan mandat untuk tidak saja dapat mengembangkan progam studi kependidikan, tetapi juga boleh mendirikan progam studi non kependidian. Pada saat itu fakultas kependidikan IPS IKIP Negeri Singaraja membuat dua jurusan non pendidikan, yaitu D3 Akuntasi dan D3 Manajemen perhotelan. Karena itulah maka dengan kekuatan hukum peraturan Presiden RI NO.11 Tahun 2006, status IKIP Negeri Singaraja kemudian berubah kebali menjadi Universitas Pendidikan Ganesha (Undiksha). Sejak status perubahan Undiksha ini, Fakultas Pendidikan IPS Undiksha kemudian terus membuka jurusan baru bidan nonpendidikan, antara lain S1 Manajeman dan S1 Akuntansi. Tetapi dengan menambah jurusan baru nonpendidikan ini menyebabkan Fakultas Pendidikan IPS justru mengalami perkembangan menjadi dua fakultas, yaitu fakultas ilmu sosial dan 
fakultas (FIS) ekonomi dan bisnis (FEB). Fakultas ilmu sosial terdiri dari tujuh jurusan yaitu, S1 Pendidikan Sejarah, S1 Pendidikan Ppkn, S1 Pendidikan Sosiologi, S1 Pendidikan Geografi, IImu Hukum, D3 Perpustakaan Dan D3 Survey Pemetaan. Sedangkan FEB terdiri dari lima jurusan yakni, S1. Ekonomi, S1 Akuntansi, S1. Manajeman, D3 Manajeman Perhotelan Dan D3 Akuntansi.

Bertambahnya ilmu hukum di fakultas ilmu sosial (FHIS). Ditahun 2015 fakultas ilmu sosial ditetapkan menjadi Fakultas Hukum Dan IImu Sosial (FHIS) dengan tujuh jurusan yaitu, $S 1$ Pendidikan Sejarah, S1 Pendidikan Ppkn, S1 Pendidikan Sosiologi, S1 Pendidikan Geografi, IImu Hukum, D3 Perpustakaan Dan D3 Survey Pemetaan

\section{Sejarah Singkat Jurusan Pendidikan Sejarah}

Jurusan Pendidikan Sejarah berdiri pada tanggal 1 Mei 1967, berdasarkan Surat Keputusan (SK) Rektor IKIP Malang Nomor BHR 732/1967, tertanggal 1 Mei 1967. SK ini secara substantif tidak berkaitan dengan pendirian Jurusan Pendidikan Sejarah, melainkan tentang pengangkatan Drs. Ketut Pugeh sebagai Ketua Jurusan Pendidikan Sejarah. Walaupun demikian, SK ini bisa dipakai dasar bagi pendirian Jurusan Pendidikan Sejarah, karena berdasarkan SK tersebut, Jurusan Pendidikan Sejarah telah bisa beroperasi sebagai suatu lembaga. Keterlibatan IKIP Malang dalam pengeluaran SK tersebut tidak bisa dilepaskan dari perguruan tinggi induk yang menaunginya, yakni IKIP Malang (IKIP Malang Mei 1967 dan IKIP Malang Cabang Singaraja tahun 1964).

Bahkan yang tidak kalah pentingnya, kedudukan Jurusan Pendidikan Sejarah semakin kokoh, sebagaimana tercermin pada SK Menteri Pendidikan dan Kebudayaan Nomor 2896/KT//SP/68, Tanggal 28 Oktober 1968 mengakui maupun menetapkan Drs. Ketut Pugeh sebagai Ketua Jurusan Pendidikan Sejarah, IKIP Malang Cabang Singaraja, di Singaraja.
Pada tahun 1982 jurusan-jurusan yang ada di lingkungan IKIP Malang Cabang Singaraja di Singaraja, bergabung dengan Universitas Udayana di Denpasar. Penggabungan ini dimaksudkan untuk memudahkan pengembangan maupun koordinasi dalam konteks peningkatan kualitas Tri Dharma Perguruan Tinggi. Jurusan-jurusan yang ada di lingkungan IKIP Malang Cabang Singaraja, membentuk sebuah Fakultas, yakni FKIP. Walaupun digabungkan dengan Universitas Udayana, namun FKIP (Pendidikan Sejarah termasuk di dalamnya) tetap berada di kota Singaraja. Dalam perkembangan selanjutnya, FKIP memisahkan diri menjadi dua fakultas, yakni FIP (Fakultas IImu Pendidikan) dan FKg (Fakultas Keguruan). Dalam konteks ini Jurusan Pendidikan Sejarah bergabung dengan FKg. Bahkan yang tidak kalah pentingnya, Jurusan Pendidikan Sejarah diberikan label baru, yakni Jurusan Pendidikan Sejarah/Antropologi.

Pemberian tambahan label Antropologi tidak semata-mata untuk memenuhi kebutuhan pasar, yakni di SMA ada mata pelajaran Antroplogi, tetapi juga memperkuat basis keilmuan kesejarahan. Dalam arti, melalui penguasaan teori-teori Antropologi diharapkan mahasiswa bisa lebih kritis, komprehensif dan mampu menggunakan

pendekatan multidimensional dalam menganalisis peristiwa-peristiwa sejarah. Label Jurusan Pendidikan Sejarah/Antropologi mulai dihilangkan sejak berlakunya kurikulum 1989 .

Perjalanan selanjutnya adalah, melalui SK Presiden No. 8 Tahun 1993, FIP dan FKg berpisah dari Universitas Udayana, membentuk sekolah tinggi, yakni STKIP. STKIP terdiri dari beberapa jurusan, salah satu diantaranya adalah Jurusan Pendidikan IImu Pengetahuan Sosial (Jurusan Pendidikan IPS). Pada tahun 2001 STKIP Negeri Singaraja ditingkatkan statusnya menjadi IKIP Negeri Singaraja, yang terdiri atas beberapa fakultas dan satu di antaranya adalah Fakultas Pendidikan IImu Pengetahuan Sosial (FPIPS). 


$\begin{array}{lr}\text { Walaupun label Antropologi } \\ \text { dihilangkan, namun secara substantif } \\ \text { Jurusan Pendidikan Sejarah } \begin{array}{r}\text { tetap } \\ \text { mengasuh mata }\end{array} \\ \text { Antropologi/Sosiologi } & \text { kuliah }\end{array}$

(Sosiologi/Antropologi), dengan beban 2223 SKS, sebagaimana tercantum pada Kurikulum 1994 - terkait dengan kewenangan kedua program PSSM. Misinya tetap sama, yakni tidak sematamata untuk memenuhi kebutuhan pasar, tetapi juga memperkuat basis ilmu kesejarahan yang mengutamakan pendekatan multidisiplin atau sejarah kritis.

Berkenaan dengan itu keluaran Jurusan Pendidikan Sejarah yang mengambil minor Sosiologi/Antropologi diberikan sertifikat. Sertifikat ini memuat aneka mata kuliah Sosiologi/Antropologi yang mereka dapatkan, lengkap dengan SKS-nya. Dengan cara ini diharapkan, pertama, keluaran Jurusan Sejarah tidak hanya berpeluang menjadi guru sejarah, tetapi juga guru Sosiologi/Antropologi. Kedua, peluang menjadi guru Sosiologi/Antropologi cukup bagus, mengingat bahwa belum ada LPTK yang mencetak guru Sosiologi/Antropologi, padahal pasar membutuhkannya. Ketiga, mengurangi kerancuan yang berlaku di sekolah (misalnya SMA), di mana banyak guru yang mengajar Sosiologi/Antropologi berasal dari keluaran Jurusan Geografi, PPKn, bahkan Pendidikan Luar Sekolah, BP, TP,dengan alasan mereka pernah mendapatkan matakuliah Sosiologi/Antropologi, yakni berbentuk pengantar sekitar 4 SKS.

Pemberian

Sosiologi/Antropologi kepada Sertifikat Jurusan Pendidikan Sejarah ternyata sangat memberikan kemanfaatan. Hal ini terbukti dari adanya kenyataan bahwa banyak keluaran Jurusan Pendidikan Sejarah bisa diangkat sebagai PNS dan atau guru honorer, tidak semata-mata karena mereka berijazah Pendidikan Sejarah, tetapi juga karena memiliki Sertifikat Sosiologi/Antropologi. Kondisi ini berlaku di Bali dan di luar Bali, yakni NTB (Lombok dan Sumbawa).
Pada tahun 2002, terjadi perubahan kurikulum sebagaimana yang digariskan dalam Surat Keputusan Mendiknas Nomor 045/U/2002 tentang Kurikulum Inti Perguruan Tinggi. Kurikulum Pendidikan Sejarah mengalami perubahan, yakni selain mencetak guru Pendidikan Sejarah, juga mengembangkan mata kuliah alternatif. Hal ini terdiri dari tiga kelompok matakuliah alternatif, yakni: Sosiologi/Antropologi; (2) Pekerja Sosial; dan (3) Kearsifan.

Berdasarkan pertimbangan agar pengembangan lembaga bisa lebih prospektif, ditambah lagi dukungan masyarakat setempat, termasuk Pemerintah Kabupaten Buleleng untuk menjadikan Singaraja sebagai kota pelajar, maka IKIP diubah menjadi universitas, yakni Universitas Pendidikan Ganesha (Undiksha). Perubahan ini berdasarkan pada Perpres Nomor 11/2006, tanggal 11 Mei 2006. Label pendidikan tetap dipertahankan untuk mengingatkan bahwa Undiksha tetap berkomitmen sebagai lembaga yang mencetak guru. Namun, di sisi yang lain Undiksha mengembangkan pula jurusan non-kependidikan. Sama halnya dengan IKIP, Undiksha terdiri dari enam fakultas, salah satu di antaranya adalah Fakultas IImu Sosial (FIS). Jurusan Pendidikan Sejarah berada di bawah Fakultas IImu Sosial.

Kurikulum yang berlaku saat ini adalah tiga kurikulum, yakni Kurikulum 2006 (tahap peralihan menuju belakukanya secara penuh kurikulum 2006) dan Kurikulum 2006. Pemberlakuan Kurikulum 2006 bertalian dengan perubahan kurikulum seperti yang digariskan dalam Undang-undang Nomor 20/2003 tentang Sistem Pendidikan Nasional, Surat Keputusan Mendiknas RI Nonor 045/U/2002 tentang Kurikulum Inti Perguruan Tinggi, Undang-undang Nomor 14 tahun 2005 tentang Guru dan Dosen, dan PP Nomor 19/2005 tentang BSNP. Pada Kurikulum 2006, MKKA ditiadakan. Kurikulum 2006 menekankan pada KBK (Kurikulum Berbasis Kompetensi). Walaupun MKKA ditiadakan, namun 
beberapa mata kuliah Sosiologi/Antropologi tetap dicantumkan pada Kurikulum 2006. Pencantumannya dimaksudkan sebagai ilmu bantu yang memperkuat kemampuan mahasiswa dalam mengembangkan pemahaman sejarah kritis. Selain itu, guru Pendidikan Sejarah diharapkan pula bisa mengajar Sosiologi/ Antropologi mengingat bahwa seperti dikemukakan di atas, guru Sosiologi/ Antropologi sangat dibutuhkan, namun LPTK yang mencetaknya belum disiapkan. Berkenaan dengan itu maka dalam waktu dekat, Jurusan Pendidikan Sejarah akan mengembangkan Jurusan Pendidikan Sosiologi/ Antropologi dan D-3 IImu Perpustakaan. Untuk itu telah dilakukan Studi Kelayakan yang dilanjutkan dengan penyusunan proposal pembukaan Jurusan Pendidikan Sosiologi/Antropologi dan D-3 IImu Perpusakaan

Jurusan Pendidikan Sejarah yang sekarang menjadi prodi pendidikan sejarah Fakultas Hukum Dan Ilmu Sosial, Universitas Pendidikan Ganesha pada saat ini sudah menggunakan kurikulum berbasis $\mathrm{KKNI}$ dengan tujuan untuk menghasilkan sumberdaya manusia yang memiliki kemampuan akademik dan profesional dibidang kesejarahan/ lulusan pendidikan sejarah diharapkan mampu menghasilkan tenaga pendidik dengan kompetensi sebagai pendidik sejarah, peneliti dalam bidang pendidikan sejarah, pramuwisata dan wirausaha dibidang pariwisata sejarah dan budaya. Dilansir dari http://fhis.undiksha.ac.id (diakses pada 09 Juli 2018)

\section{Sejarah Singkat Jurusan D3 Perpustakaan}

Jurusan D3 Perpustakaan Fakultas

Hukum Dan IImu Sosial Universitas Pendidikan Ganesha di rancang untuk menghasilkan sumber daya manusia yang memiliki kemampuan akademik dan profesional di bidang perpustakaan. Lulusan diploma III perpustakaan diharapkan mampu mengelola institusi perpustakaan dengan memanfaatkan teknologi informasi di bidang perpustakaan. Selain itu, mahasiswa juga dibekali dengan beberapa keahlian, seperti bahasa inggris, manajemen kearsipan, dan lainnya untuk dapat menunjang profesi kepustakawanannya. Jurusan D3 Perpustakaan merupakan bagian dari Jurusan Pendidikan Sejarah karna pada awalmula berdirinya jurusan ini yaitu dari Jurusan Pendidikan Sejarah, dan tidak hanya jurusan D3 saja namun juga jurusan Pendidikan Sosiaologi. Jurusan Perpustakaan ini juga memiliki visi dan misi untuk menunjang sumberdaya manusia yang berada di jurusan tersebut.

Progam Himpunan Mahasiswa Jurusan Pendidikan Sejarah

\section{Clio Fun Day}

Clio fun daya (kegiatan senang2/

bersenang ria) merupakan sebuah kegiatan yang di miliki oleh jurusan sejarah, clio fun day merupakan salah satu progam kerja HMJ sejarah yang dapat dijadikan contoh untuk meningkatkan solidaitas sosial dalam kehidupan masyarakat yang majemuk. Clio fun day atau bisa kita sebut kegiatan senang-senang atau bersenang ria, tujuan dari adanya kegiatan ini tak lain untuk memperkuat hubungan sesama anggota dalam HMJ maupun semua mahasiswa pendidikan sejarah,

\section{Bakti Sosial}

Bakti sosial merupakan progam yang di miliki oleh jurusan pendidikan sejarah dan D3 Perpustakaan, tak lain tujuannya untuk kesejahteraan masyarakat. Dengan dikemas bakti sosial ini mahasiswa harus terlibat langsung didalamnya supaya mengetahui kehidupan masyarakat secara luas. Tidak hanya itu saja dengan bakti sosial ini para anggota HMJ juga terlibat dalam bakti sosial yang tujuannya tak lain untuk meningkatkan solidaritas antar anggota baik yang senior maupun yang junior

\section{Clio Ajang Sana}

Clio ajang sana atau sering dikenal oleh mahasiswa sejarah yaitu (ratam jurusan/okk). Dengan diadakannya ratan jurusan ini tujuannya tak lain untuk membentuk sikap kekeluargaan baik 
senior dengan juniar lebih-lebih dengan mahasiswa baru atau disebut dengan istilah (MABA). Momen ini sangat penting dan bisanya progam ini dilakukan hanya sekali dalam setahun. Isi dari kegiatan ini cukup banyak mulai dari pengenalan jurusan, pengenalan dosen, pengenalan progam dan sebagainya. Tujuannya untuk menarik keluarga baru supaya lebih betah di jurusan itu sendiri. Tak lupa juga dengan adanya game setelah paruh kedua kegiatan materi yang di sampaikan oleh panitia ratam itu sendiri

\section{Clio Club}

Clio club (diskusi seluruh mahasiswa bersama dosen membahasa tentang berita-berita/fenomena terhangat). Dalam hal ini untuk menambah wawasan dan pengtahuan mahasiswa, namun bukan itu saja maksud dari kegiatan ini, yaitu untuk memperkuat solidaritas antar mahasiswa. Mahasiswa wajib hadir dalam kegiatan ini baik senior maupun juniar. Tidak hanya mahasiswa saja namun dosenpun harus ikut hadir. Dengan demikian kita berkumpul semua dalam sebuah tempat untuk membahas isu atau fenomena hangat yang sedang terjadi

\section{Suka Duka Mahasiswa}

Progam Suka duka ini memang tidak dijadwalkan karena ini menyangkut rasa kekeluargaan dari semua siakademik jurusan sejarah. Yang dimaksud dengan rasa kekeluargaan yaitu ketika salah satu mahasiwa atau pun dosen yang sedang mengalami musibah atau kedukaan kita akan membantu baik melalui materi maupun non materi sebagai rasa kekeluargaan itu sendiri. Hal ini memang tidak diharapkan terjadi, namun tidaklah mungkin kita tidak akan mendapatkan kedukaan, dengan harapan beban orang yang mengalami kedukaan terselesaikan meskipun tidak harus 100\%

\section{Malam Keakraban Sejarah (MKS)}

(Mks) atau malam keakraban sejarah merupakan malam yang dinanti nantikan oleh setiap mahasiwa itu sendiri, disini mahasiswa dari setiap semester menampilkan kreasi-kreasinya baik berupa drama, musikal, tarian dll.
Berkumpul dalam satu tempat menikmati keindahan secara bersama

\section{Pemeliharaan Taman Sejarah}

Progam ini merupakan progam yang tidak terjadwalkan namun progam ini melatih kita untuk kekompakan biasanya kita datang berkumpul dari semua kalangan mahasiswa baik senior maupun junior, tujuan yaitu bersama sama memberiskan dan merapikan taman sejarah yang dimilikinya. Terkadang juga ada yang tidak hadir dalam acara ini, namun pihak HMJ sudah mengantisipasi terjadinya itu dengan cara enerapkan denta bagi yang tidak hadir dalam pembersihan tamn sejarah. Tidak hanya satu atau dua orang yang harus memelihara taman ini namun semua mahasiswa wajib hukumnya untuk menjaga dan merawatnya

\section{Progam Himpunan Mahasiswa Jurusan Perpustakaan \\ Menggalang Dan Menyalurkan Bantuan Kemanusiaan}

Mengalang dana dan menyalurkan bantuan kemanusiaan ini merupakan suatu progam yang di miliki oleh pendidikan sejarah untuk membatu dan meringankan beban masyarakat yang mengalami kedukaan. Disini mahasiswa berperan untuk melepaskan beban masyarakat itu dengan cara

Setiap mahasiswa menggalang dana baik di jalan raya, pertokoan dll secara bersama sama. Setalah selesai penggalangan dana semua mahasiswa berkumpul menjadi satu untuk menghidung hasil dan menggumpulkan materi yang di butuhkan oleh masyarakat. Setelah selesai maka tahab berikutnya yaitu seluruh mahasiswa ikut serta dalam pemberian sembako kepada masyarakat

\section{Hut Jurusan}

Adalah hal yang paling di nantinanti oleh setiap mahasiswa. Momen ini terjadi atau dilakukan hanya setahun sekali. Maka disinilah kesempatan HMJ untuk pempersatukan mahasiswa. Semua mahasiswa ikut andil dalam kegiatan ini, 
mulai dari persiapan sampai acara dimulai bahkan sampai acara itu selesai

Memang setiap jurusan memiliki kegiatan ini namun tiap jurusan memiliki kegiatan ini yang berbeda

Contohnya HMJ sejarah menampilakan drama yang berkaitan dengan sejarahsejarah tempo dulu seperti drama layon sari,sejarah perang, sejarah kerajaan dll

Sedangkan D3 Perpustakaan yaitu dengan menampilkan dongeng-dongen dll.

\section{Lomba Mendongeng}

Lomba ini hanya di miliki oleh D3 Perpustakaan yang mana pesertanya dari kalangan mahasiswa itu sendiri, namun sekarang bukan hanya dari kalangan mahasiswa saja, pesertannya juga dari kalangan pelajar seperti SMP, SMA DII. Dalam kegiatan lomba ini setiap mahasiswa harus ikut andil dalam mempersiapkan kebutuhan-kebutuhan lomba. Mulai dari sarana dan prasarana, juri dan materi lainnya. Dengan melalui kegiatan lomba ini organisasi memiliki peran penting untuk menumbuhkan nilai solidaritas antar anggota dengan cara bekerja sama, saling menyumbang ide, gagasan dan kemampuan baik berupa fisik dll. Ajang lomba seperti ini selain memper kokoh persaudaraan juga melatih kerja sama antar anggota HMJ untuk tercapainya sebuah kegiatan

Namun dari semua kegiatan dan progam yang dimiliki oleh kedua jurusan tersebut tentu memiliki hambatan dalam mewujutkan terlaksananya sebuah kegiatan tersebuat. Disini penulis menyimpulkan dari semua kegiatan dan progan tersebut memiliki hambatan yang komplek. Untuk lebih jelasnya penulis akan membahasa permasalahan hambatan ini di pembahasan berikutnya

\section{Hambatan Yang Terdapat Di Himpunan Mahasiswa Jurusan Dalam Menumbuhkan Sikap Solidaritas Sosial Antar Mahasiswa}

\section{Ekonomi}

Dalam hal ini pada dasarnya ekonomi merupakan salah satu aspek yang terjadi dalam keseharian manusia. Aspek ini mengakibatkan adanya transaksi antara satu individu dan individu lainnya yang bertujuan untuk memenuhi kebutuhan hidup sehari-hari. Segala upaya dalam memenuhi kebutuhan organisasi untuk mencapai suatu tingkatan kemakmuran atau keberhasilan dalam sebuah oragnisasi itu sendiri perlu adanya partisipasi anggota dalam hal ekonomi

\section{Sumberdaya Manusia}

Tak dapat dipungkiri jika dalam sebuah organisasi (SDM) adalah salah satu faktor yang sangat penting bahkan tidak dapat dilepaskan dari sebuah organisasi, baik institusi maupun perusahaan. SDM juga merupakan kunci yang menentukan perkembangan organisasi itu sendiri. Pada hakikatnya, SDM berupa manusia yang dipekerjakan di sebuah organisasi sebagai penggerak, pemikir dan perencana untuk mencapai tujuan organisasi itu sendiri

\section{Kurangnya Partisipasi Mahasiswa}

Hal utama yang membuat hidupnya sebuah organisasi yaitu partisipai seluruh anggota $\mathrm{hmj}$ itu sendiri. partisipasi melibatkan mental dan emosi seseorang kepada pencapaian tujuan dan ikut bertanggung jawab di dalam organisasi itu sendiri. Dalam hal ini keterlibatan anggota sangat penting baik secara pemikiran maupun tenaga. dalam pelaksanaannya anggota juga ikut memikul tanggung jawab sesuai dengan tingkat kematangan dan tingkat kewajibannya. Partisipasi itu baik dalam bidang-bidang fisik maupun bidang mental serta penentuan kebijaksanaan. 


\section{Egoisme}

Dalah sebuah organisasi jika mengedepankan sikap ini, maka organisasi tersebut akan mengalami gangguan bahkan goncangan menuju kehancuran, jika sikap ego yang dikedepankan oleh anggota maka akan menghambat perkembangan dari organisasi itu sendiri

\section{Kedisiplinan}

Disiplin merupakan suatu sifat yang dimiliki seseorang untuk taat dan bisa mengendalikan diri, agar tetap mematuhi aturan yang telah dibuat atau disepakati. Disiplin merupakan suatu sikapatau prilaku yang tentunya diharapkan oleh banyak orang khususnya orang yang berpendidikan. Tentunya disiplin sangat dibutuhkan karna dapat membantu suatu kegiatan agar dapat berjalan dengan lancar sesuai dengan apa yang diharapkannya. Tentu disiplin tidak lepas dari aturan, norma, organisasi, kerja sama dan lain sebagainya.

Aspek Yang Dapat Dijadikan Sebagai Suplemen Pembelajaran Dalam Mata Pelajaran Sosiologi Di SMA

\section{Nilai gotong royong/kerja sama}

Kita sebagai makhluk sosial membutuhkan sesama dalam mencapai kesejahteraan yang baik. Tidak dapat dipungkiri bahwa gotong royong merupakan aset budaya yang harus senantiasa dijaga dan menjadi pola sikap masyarakat. Gotong royong pun mampu penciptakan suasana yang harmonis antara masyarakat yakni seringnya masyarakat dalam menjalin silaturrahmi, melakukan kerjasama, maka terjalinlah solidaritas yang dapat menumbuhkan rasa simpati dan empati masyarakat sehingga menjadi alat perekat untuk memperkuat dan mempererat hubungan masyarakat bila dimanfaatkan dapat menjadi senjata yang ampuh dalam menghadapi pembangunan nasional.

Gotong royong/Kerja sama merujuk pada praktik seseorang atau kelompok yang lebih besar yang bekerja di khayalak dengan tujuan atau kemungkinan metode yang disetujui bersama secara umum. Kerja sama dapat sejumlah ranah bisnis, pertanian, dan perusahaan dll dapat diwujudkan dalam bentuk kerja sama. Kerja sama umumnya mencakup paradigma yang berlawanan dengan kompetisi. Banyak orang yang mendukung kerja sama sebagai bentuk yang ideal untuk pengelolaan urusan perorangan.

\section{Nilai toleransi}

Tidak dapat kita pungkiri jika nilai toleransi ini sangat penting. Dalam kehidupan yang majemuk seperti indonesia ini. Setiap orang harus mulai mengenal bahwa hal baik yang dilakukan dalam masyarakat, dalam hidup bersama akan membawa kegembiraan, kebahagiaan bagi semua orang. Kebiasaan berbuat baik dan bertanggung jawab terhadap akibat yang timbul dari perbuatan yang dilakukan haruslah menjadi cerminan tingkah laku sehari-hari. Penerapan nilai toleransi sesama umat maupun umat lain sangatlah penting bagi kehidupan sehari-hari apalagi dalam sebuah organisasi HMJ yang anggotanya dari berbagai suku, ras, budaya, agama

Nilai toleransi yang dapat kita petik dalam sebuah organisasi, khususnya organisasi HMJ yang berada di dunia kampus yaitu nilai kekeluargaan, nilai saling memiliki karena kita sama dan bersaudara

\section{Nilai tanggung jawab}

Rasa tanggung jawab adalah suatu pengertian dasar untuk memahami manusia sebagai makhluk susila, dan tinggi rendahnya akhlak yang dimilikinya. Terkait rasa tanggung jawabsebaiknya manusia melandasi anggapannya dengan mengakui kenyataan bahwa mansuia dalam hubungan yang sempit dan luas memerlukan satu sama lain untuk mewujudkan nilai-nilai kehidupan yang dirasanya baik dan menunjang eksistensi dirinya. Rasa tanggung jawab kemudian berkembang bukan hanya pada tataran personal, namun selalu dikaitkan dengan hubungan dengan orang lain, sehingga dapat dibuat dalam sistem hukum, bahkan hukum pidana. Seseorang yang terhubung 
dengan pihak-pihak lain tidak bisa lepas dari rasa tanggung jawab yang melekat pada dirinnya. Apalagi dalam ranah organisasi, kita harus memiliki tanggung jawab bersama untuk membentuk sebuah organisasi yang baik. Jika setiap anggota memiliki tanggung jawab yang besar terhadap organisasi maka tidak akan muncul suatu sikap egois karena kita merasa saling memiliki

Nilai tanggung jawab yang dapat kita ambil dalam sebuah organisasi yaitu. Tanggung jawab moral. Tanggung jawab identik dengan tindakan moral. Tanggung jawab moral melingkupi tiga unsur: kebebasan bertindak dan tindakan integral tanggung jawab (lahir dari hati nurani). Tanggung jawab atas kebersamaan, tidak saling menyalahkan antara satu dengan yang lain. Semua yang berada di dalam organisasi wajib untuk bertanggung jawab atas organisasinya itu sendiri supaya tidak ada anggapan negatif sesama anggota

\section{SIMPULAN}

Kegiatan organisasi merupakan suatu wadah untuk menyalurkan minat dan bakat mahasiswa yang nantinya akan berorientasi kepada pengabdian masyarakat, penlitian, aktualisasi diri dan peningkatan kapasitas keilmuan yang diselenggarakan oleh pihak universitas, fakultas, maupun dari organisasi kemahasiswaan yang terdaftar. Kegiatan ini bertujuan untuk menumbuh kembangkan pribadi peserta didik yang sehat jasmani dan rohani, bertakwa kepada Tuhan Yang Maha Esa, memiliki kepedulian dan tanggung jawab melalui berbagai kegiatan yang positif dibawah naungan lembaga kependidikan.

Peran kegiatan organisasi mahasiswa merupakan pendorong yang dapat memacu prestasi belajar yang lebih baik. Dengan mengikuti organisasi ekstrakurikuler mahasiswa dapat memperluas wawasan, menyalurkan bakat, minat serta membentuk suatu pribadi yang kritis dimana hal itu tidak diperoleh di dalam kelas formal. Melalui kegiatan organisasi, mahasiswa juga akan memiliki peluang yang tinggi pula dalam mencapai prestasi belajar yang baik, karena secara tidak langung mahasiswa dapat menggabungkan pengalamanpengalaman yang diperoleh dalam organisasi kedalam mata kuliah yang diperoleh didalam kelas.

Mahasiswa yang tergabung dan mengikuti organisasi biasanya akan terlihat lebih aktif di bandingkan dengan mahasiswa yang setiap harinya hanya pergi kulian dan setelah pelajaran pulang. Dalam organisasi mahasiswa di ajarkan bagaimana cara berbicara yang baik dan bagaimana menyikapi suatu permasalahan. Tentunya ini akan menjadi bekal yang sangat menarik saat mahasiswa sudah lulus dan masuk dalam dunia masyarakat yang sebenarnya.Keterlibatan mahasiswa dalam organisasi kemahasiswaan mendorong pembentukan sikap yang akan mempengaruhi keaktifan mahasiswa dalam organisasi kemahasiswaan.

\section{DAFTAR RUJUKAN}

Abdul, Syani. (1994). Sosiologi Sistematika, Teori, Dan Terapan. Jakarta: PT. Bumi Aksara

Damsar. (2010). Pengantar Sosiologi Politik. Jakarta: Kencana Prenada Suplemen Group

Emzir. 2015. Metodelogi penelitian pendidikan: kuantitatif dan kualitatif. Jakarta: Rajawali

Muhammad, Armi. (2007). Komunikasi Organisasi. Jakarta: PT. Bumi Aksara

M,Jazuli. (2014). Sosiologi Seni (Pengantar Dan Model Studi Seni Edisi 2). Yokyakarta: Graha IImu

Soekanto, Soerjono.2010. Pengantar Sosiologi Kelompok. Bandung: Remadja Karya. 
Sugiyono. 2010. Metode penelitian pendidikan. Bandung: Alfabeta

S. Nasution, M.A. (2008). Metode Research Penelitian IImiah. Jakarta: Bumi Aksara

Suharismi Arikunto. (1993). Prosedur Penelitian Suatu pendekatan Praktek. Jakarta: Rineka

Rahmat, Pupu Saeful. 2012. Penelitian kualitatif. Jurnal Equilibrium. Vol.5. No.9 (diakses pada tanggal 16 maret 2018) http://fhis.undiksha.ac.id (diakses pada 09 Juli 2018)

http://fhis.undiksha.ac.id/profil/d3-

perpustakaan/ (di akses pada 09 Juli 2018)

https://rumahinspirasi.com/18-nilai-dalampendidikan-karakter-bangsa/ (di akses pada 03 November) 